\title{
A new fossil provannid gastropod from Miocene hydrocarbon seep deposits, East Coast Basin, North Island, New Zealand
}

\author{
Kristian P. Saether, Crispin T.S. Little, and Kathleen A. Campbell \\ Acta Palaeontologica Polonica 55 (3), 2010: 507-517 doi: http://dx.doi.org/10.4202/app.2009.1112
}

Provanna marshalli sp. nov. is described from Early to Middle Miocene-age fossil hydrocarbon seep localities in the East Coast Basin, North Island, New Zealand, adding to 18 modern and three fossil species of the genus described. Modern species are well represented at hydrothermal vent sites as well as at hydrocarbon seeps and on other organic substrates in the deep sea, including sunken wood and whale falls. Described fossil Provanna species have been almost exclusively reported from hydrocarbon seep deposits, with a few reports of suspected fossil specimens of the genus from other chemosynthetic environments such as sunken wood and large vertebrate (whale and plesiosaurid) carcasses, and the oldest occurrences are dated to the Middle Cenomanian (early Late Cretaceous). The New Zealand fossil species is the most variable species of the genus described to date, and its shell microstructure is reported and found to be comparable to the fossil species Provanna antiqua and some modern species of the genus.

Key words: Mollusca, Gastropoda, Provannidae, Provanna, hydrocarbon seeps, Miocene, East Coast Basin, New Zealand.

Kristian P. Saether [k.saether@auckland.ac.nz] and Kathleen A. Campbell [ka.campbell@auckland.ac.nz], School of Environment, Faculty of Science, University of Auckland, Private Bag 92019, Auckland Mail Centre, Auckland 1142, New Zealand; Crispin T.S. Little [c.little@see.leeds.ac.uk], School of Earth and Environment, University of Leeds, Leeds, LS2 9JT, United Kingdom.

This is an open-access article distributed under the terms of the Creative Commons Attribution License (for details please see creativecommons.org), which permits unrestricted use, distribution, and reproduction in any medium, provided the original author and source are credited. 
For Full text $(1,316.3 \mathrm{kB})$ 